\begin{tabular}{lcc}
\hline Volume 21 & Nomor 2, Juli 2020 & Halaman 127-141 \\
URL: https://jurnal.unej.ac.id/index.php/SEMIOTIKA/index & E-ISSN: 2599-3429 & P-ISSN: 1411-5948 \\
\hline
\end{tabular}

\title{
REPRESENTASI KEARIFAN LOKAL DARI NOVEL KE FILM RAKSASA DARI JOGJA: KAJIAN EKRANISASI
}

\section{A REPRESENTATION OF YOGYAKARTA LOCAL WISDOM IN FROM NOVEL TO FILM IN RAKSASA DARI JOGJA: ECRANIZATION ANALYSIS}

\author{
Ajeng Yuditya Siswara ${ }^{1}$, Heru S.P. Saputra ${ }^{2} *$ Titik Maslikatin $^{3}$ \\ ${ }^{1}$ Alumni Fakultas Ilmu Budaya Universitas Jember \\ ${ }^{2,3}$ Fakultas Ilmu Budaya Universitas Jember \\ *Corresponding Author: herusp.saputra.fib@unej.ac.id \\ Informasi Artikel: \\ Dikirim: 17/4/2020; Direvisi: 5/6/2020; Diterima: 12/7/2020
}

\begin{abstract}
This article analyzes the ecranization pattern between the novel Raksasa Dari Yogya and the adapted film. Filmize novel usually changes the story text's content because not all novel story text content can be moved on the screen. This study aims to get the changes that occur in the novel's adaptation pattern to the form of a film medium, and the shape of representations existed in the two works. This study uses an ecranization perspective. The methodology used in this study is qualitative because the data are in the form of narrative text in novels and visual texts which are the results of the film captured Raksasa Dari Yogya. The data collection method was collected by reading, taking notes, watching, recording film source data, and processing it. Data analysis is in the form of interpretation of data obtained from novel texts and films. The study results show that there are changes: reducing, adding, or varying modifications in terms of the content of the story text. It is caused by the difference between the media used between novels and films. Books and movies reveal Yogyakarta local wisdom representations in the form of arts and tourism. The local wisdom depicted in novels and movies reflects Yogyakarta culture's richness, strengthening a region's identity. The changes can make the film more attractive without changing the substance of the novel as a whole.
\end{abstract}

Keywords: ecranization, Jogja, local wisdom, representation

\begin{abstract}
Abstrak
Artikel ini mengkaji pola ekranisasi antara novel Raksasa dari Jogja dengan film hasil adaptasinya. Novel yang mengalami adaptasi menjadi sebuah film, seringkali mengakibatkan terjadinya perubahan dari sisi konten teks cerita. Karena tidak semua konten teks cerita novel dapat divisualisasikan ke dalam bentuk film. Tujuan kajian ini untuk mengungkapkan perubahan-perubahan yang terjadi dalam pola adaptasi novel ke bentuk medium film maupun wujud representasi-representasi yang terdapat dalam kedua karya tersebut. Kajian ini menggunakan perspektif analisis ekranisasi. Adapun metodologi yang dipergunakan dala kajian ini adalah metodologi kualitatif. Karena datadata berupa teks naratif dalam novel maupun teks visual yang merupakan hasil capture tehadap film Raksasa dari Jogja. Metode pengumpulan data dilakukan dengan membaca, mencatat, menonton, mencatat data-data sumber film, dan mengolah data. Analisis data berupa interpretasi terhadap data-data yang diperoleh dari teks-teks novel dan film. Hasil kajian menunjukkan adanya perubahan-perubahan berupa: penciutan, penambahan, maupun perubahan bervariasi dari sisi konten teks cerita. Karena media yang digunakan
\end{abstract}


antara novel dan film berbeda. Selain itu, novel dan film mengungkapkan representasi kearifan lokal Yogyakarta dalam bentuk kesenian dan pariwisata. Representasi kearifan lokal yang digambarkan di novel dan film mencerminkan kekayaan budaya Yogyakarta yang berimplikasi terhadap penguatan identitas suatu daerah. Perubahan-perubahan yang terjadi mampu membuat film menjadi lebih menarik tanpa merubah substansi novel secara keseluruhan.

Kata kunci: ekranisasi, Jogja, kearifan lokal, representasi

\section{PENDAHULUAN}

Industri hiburan di Indonesia beberapa waktu belakangan ini menunjukkan adanya trend film yang berasal dari hasil adaptasi novel. Novel yang diadaptasi ke bentuk film merupakan karya-karya yang mendapatkan antusiasme masyarakat. Indikasinya bisa diukur dari seberapa banyak novel tersebut dicetak ulang. Harapannya agar film akan memperoleh kesuksesan di pasar industri perfilman sebagaimana keberhasilan novel memperoleh keuntungan kapital yang besar dari daya jual di industri perbukuan. Karena produksi film dalam konteks industri hiburan memang diorientasikan sebagai komoditas kapital. Ada kepentingan ekonomi di balik produksi film. Salah satu ciri utama komoditas adalah orientasi perekonomian pasarnya (Fiske, 2011:3).

Film hasil adaptasi dari novel akan menarik perhatian penonton, terutama dari para pembaca novel tersebut. Sebagai penonton, mereka akan menilai apakah film tersebut sesuai dengan ekspektasi sebagaimana saat mereka membaca novelnya. Sementara itu, harapan penulis skenario film bahwa film yang diproduksinya akan mendapatkan apresiasi dari masyarakat yang sama antusiasmenya dengan novelnya. Karena ukuran keberhasilan film di industri perfilman terletak pada aspek marketability dan playability. Bagaimana film diterima pasar maupun penonton (Keerigan, 2010:41).

Adaptasi novel ke film dikenal dengan istilah ekranisasi. Ekranisasi adalah proses adaptasi dari novel ke film. Ekranisasi pada umumnya dilakukan pada karya-karya yang mendapat sambutan hangat dari khalayak. Ekranisasi merupakan pelayarputihan atau pemindahan/pengangkatan sebuah novel ke dalam film. Dalam bahasa Perancis, ecran berarti layar. Menurut Eneste (1991:60) ekranisasi dapat dikatakan proses perubahan, karena pemindahan novel ke layar putih mau tidak mau mengakibatkan timbulnya berbagai perubahan. Pada satu sisi, novel merupakan hasil kreasi individual yang merupakan hasil kerja perseorangan yang mempunyai pengalaman, pemikiran, ide, atau hal lain yang ditulis menjadi sebuah karya novel. Karya yang akan dibaca oleh para penikmat sastra. Lain halnya dengan pembuatan film. Film merupakan hasil kerja sama seluruh elemen dalam produksi film, seperti sutradara, artis, juru kamera, penulis skenario, penata artistik, pemata musik, penata lampu, penata suara, maupun crew film lainnya. Keharmonisan kerja sama antarelemen tersebut menentukan keberhasilan produksi film, baik secara artistik, konten cerita, maupun kualitas gambar dan pengadegannya. Oleh karena itu, seringkali dalam proses penggarapannya terjadi perubahan ketika mengadaptasi novel ke film. Dengan kata lain, ekranisasi berarti proses perubahan dari sesuatu yang dihasilkan secara individual menjadi sesuatu yang dihasilkan secara bersama-sama (gotong royong) (Eneste, 1991:60).

Film Raksasa dari Jogja karya sutradara Monty Tiwa dan penulis skenario Ben Sihombing merupakan hasil ekraniasasi dari novel berjudul sama Raksasa dari Jogja karya 
Dwitasari. Novel yang telah cetak ulang hingga sebanyak tiga kali ini pertama kali diterbitkan pada Oktober 2012, disusul cetakan kedua November 2012, dan cetakan ketiga November 2012. Cetakan pertama hingga ketiga berlangsung yang hanya satu bulan saja. Hal ini menunjukkan bahwa novel Raksasa dari Jogja mendapat apresiasi yang baik dari masyarakat. Fakta tersebut membuat pekerja film tertarik untuk mengadaptasi novel ke bentuk film. Tujuannya agar mendapat respons yang tinggi dari masyarakat seperti pada novelnya.

Film Raksasa dari Jogja dirilis pertama kali di bioskop tanggal 31 Maret 2016, sedangkan novelnya diterbitkan pada Oktober 2012. Film ini tidak menampilkan hal negatif dalam porsi yang eksploitatif. Dalam film ini penyusunan dialog pun wajar dan menghindari pleonasme atau pemakaian kata yang mubazir (berlebihan) yang sebenarnya tidak perlu (Poerwadarminta, 1979:761). Pembangunan setiap karaktenya berhasil disampaikan secara alami. Namun, tetap bisa seimbang dengan tujuan film sebagai kisah roman dan tidak terlalu berat. Latar belakang tokohnya digambarkan mengalami berbagai tragedi-tragedi. Meskipun begitu, film ini tetap disajikan secara ringan dan menyampaikan harapan akan kebahagiaan pada tokoh protagonisnya.

Kota Yogyakarta menjadi latar tempat utama pada novel yang telah difilmkan ini. Tokoh utama diceritakan memiliki kesan mendalam terhadap kota tersebut. Karena menjadi tempat tinggal pada masa kecilnya yang menghadirkan banyak kenangan yang indah. Novel ini memvisualkan keindahan tempat-tempat wisata, adat tradisional yang masih terjaga, dan kearifan lokal lainnya di Yogyakarta. Oleh sebab itu kota Yogyakarta menarik untuk dijadikan latar penceritaan sebuah novel atau film. Artinya, segala hal yang berkenaan dengan kota Yogyakarta merupakan wujud dari representasi dari pemvisualisasian latar dalam novel dan film. Representasi merupakan sebuah imaji atau penyajian kembali kenyataan dalam bentuk visual dan verbal yang menyiratkan makna tertentu. Representasi dapat dianggap sebagai medan perang kepentingan atau kekuasaan, bentuk visual dan verbal mengartikan bahwa representasi memiliki matrealitas tertentu yang dapat dibaca atau dilihat serta bisa diproduksi, ditampilkan, digunakan, dan dipahami dalam konteks sosial tertentu (Budianta dalam Anoegrajekti, 2010:111). Representasi adalah tindakan yang menghadirkan sesuatu. Dapat berupa manusia, peristiwa atau kejadian maupun objek di luar dirinya yang biasanya berupa tanda atau simbol. Representasi belum tentu bersifat nyata tetapi dapat pula menunjukkan dunia khayalan, fantasi, dan ide-ide abstrak. Konsep abstrak yang terdapat dalam otak, diterjemahkan dalam bahasa yang lazim agar dapat dihubungkan dengan konsep tertentu (Hall, 1997:28).

Representasi yang dihadirkan di film hasil dari adaptasi novel Rakasa dari Jogja harus berhadapan dengan konsepsi ekranisasi. Karena karya hasil ekranisasi cenderung tidak lagi terbebani oleh upaya untuk membangun popularitas, tetapi justru terbebani oleh popularitas yang telah disandang oleh karya yang menjadi sumber ekranisasi. Hal ini dilatarbelakangi bahwa sejak awal ekranisasi diniatkan sebagai bentuk pengejawantahan, maka idealnya substansi film hasil ekranisasi sama dengan substansi novel (Saputra, 2009:44 - 45). Akan tetapi, konten cerita dalam film Raksasa dari Jogja mengalami perubahan dari sumber asalnya novel Raksasa dari Jogja. Menurut Damono (2018:105) proses pengubahan akan menghasilkan bentuk yang berbeda dari sumbernya. Pernyataan tersebut dikuatkan oleh pendapat Eneste (1991:60 - 67) bahwa proses ekranisasi dapat berupa perubahan, penciutan, penambahan, dan perubahan bervariasi. Berdasar pada latar belakang tersebut, maka artikel 
ini akan mengkaji dari perspektif ekranisasi bentuk representasi dari aspek kearifan lokal di Yogyakarta, baik yang terdapat di novel maupun film Raksasa dari Jogja sebagai karya dari adaptasi.

\section{METODE}

Prosedur utama dalam melakukan penelitian membutuhkan metode penelitian. Hal ini terkait dengan kaidah ilmiah yang harus dipenuhi dalam aktivitas penelitian. Menurut Sugiyono (2013:2) metode penelitian pada dasarnya merupakan cara ilmiah untuk mendapatkan data dengan tujuan dan kegunaan tertentu. Metode yang digunakan dalam penelitian ini adalah metode penelitian kualitatif. Metode kualitatif menurut Bogdan dan Taylor (dalam Moleong, 2010:4) merupakan prosedur penelitian yang menghasilkan data deskriptif yang berupa kata-kata tertulis atau lisan dari orang-orang dan perilaku yang dapat diamati.

Penelitian dilakukan dengan dua tahap, yaitu pengumpulan data dan analisis data. Menurut Faruk (2012:25) teknik pengumpulan data adalah seperangkat cara yang bertujuan mengumpulkan fakta-fakta yang berhubungan dengan masalah penelitian. Tahap pengumpulan data dilakukan dengan menggunakan empat cara, yaitu membaca, menonton, mencatat, dan mengolah data dengan mengklasifikasikan data-data. Data dalam kajian ini berupa teks konten cerita di dalam novel dan capture adegan dalam film. Tahapan analisa data dilakukan dengan mengelompokkan data yang diperoleh yang disesuaikan dengan teori ekranisasi dan representasi serta fokus kajian. Menurut Sugiyono (2013:335) teknik analisis data adalah proses mencari data, menyusun secara sistematis data yang diperoleh dari hasil wawancara, catatan lapangan, dan dokumentasi dengan cara mengorganisasikan data ke dalam kategori, menjabarkan ke dalam unit-unit, melakukan sintesis, menyusun ke dalam pola memilih mana yang penting dan yang akan dipelajari, dan membuat kesimpulan sehingga mudah dipahami oleh diri sendiri maupun orang lain. Adapun dalam kajian ini, proses analisis data dimulai dengan menelaah seluruh data yang diperoleh dari berbagai sumber. Berdasarkan paparan identifikasi fokus kajian yang terdapat di latar belakang masalah, analisis dalam kajian ini dilakukan untuk mengungkapkan atau pun mendeskripsikan peubahan-perubahan pada konten teks cerita novel ke film dan wujud representasi berupa kearifan lokal dari kedua karya tersebut.

\section{HASIL DAN PEMBAHASAN}

Novel yang diekranisasi ke dalam film tidak dapat dipungkiri berpotensi untuk berkembang, melenceng, atau melebar (Simbolon dalam Saputra, 2009:45). Salah satu proses ekranisasi adalah perubahan bervariasi. Perubahan novel Raksasa dari Jogja ke bentuk film hasil adaptasinya mengalami perubahan bervariasi. Ekranisasi memungkinkan terjadinya variasi-variasi tertentu antara novel dan film. Dengan adanya variasi-variasi tersebut, film Raksasa dari Jogja yang didasarkan atas novel menunjukkan adanya perubahan yang tidak sesuai dengan novel yang menjadi referensi adaptasinya. Variasi-variasi tersebut muncul karena media, alat-alat antara novel dan film berbeda. Waktu putar film yang terbatas 
Representasi Kearifan Lokal dari Novel ke Film Raksasa dari Jogja: Kajian Ekranisasi (Ajeng Yuditya Siswara, Heru S.P. Saputra, Titik Maslikatin)

mengakibatkan tidak semua hal dan persoalan yang terdapat dalam novel dapat dipindahkan semua ke dalam film. Variasi-variasi tersebut terjadi pada latar, alur, dan tokoh.

\section{Perubahan Bervariasi}

Pola adaptasi dari novel ke medium film Raksasa dari Jogja menunjukkan terjadinya perubahan bervairiasi pada alur, latar, dan tokoh. Berikut sajian data dan analisis data terkait dengan perubahan bervariasi pada alur, latar, dan tokoh dalam proses ekranisasi novel ke film Raksasa dari Jogja.

\section{Perubahan pada Alur}

Novel Raksasa dari Jogja di awali dengan pengenalan tokoh Bianca yang telah lulus SMA dan begitu menyukai buku-buku fiksi. Hal ini terlihat dari beberapa koleksi buku fiksi yang ia miliki dan tertata rapi di dekat meja belajar. Buku karya fiksi yang menjadi kegemarannya adalah Biola Tak Berdawai.

Bianca menarik napas lega. Selesai. Tak ada lagi rumus-rumus fisika dan matematika. Tatapannya mengarah pada koleksi buku-buku fiksi yang tertata rapi di dekat meja belajar. Matanya menjamah setiap buku yang terletak di sana. Detail judul diperhatikannya dengan seksama. Tinggi rak buku itu melebihi tinggi Bianca, hampir dua meter. Ia berjinjit. Jemarinya bersemangat meraih buku bersampul hitam, Biola Tak Berdawai, Seno Gumira Ajidarma. (Raksasa dari Jogja:1).

Data menggambarkan tahap pengenalan di awal novel yang menghadirkan cerita tentang kegemaran tokoh Bianca terhadap buku- buku fiksi, dibandingkan dengan buku-buku terkait matematika dan fisika. Buku-buku fiksi dipilihnya karena tidak membuatnya merasa pusing. Hal berbeda dirasakan ketika membaca buku soal Matematik dan Fisika. Bianca begitu antusias saat ia bisa menyentuh kembali koleksi buku-buku fiksinya yang tertata rapi di kamarnya. Buku karya fiksi berjudul Biola Tak Berdawai menjadi salah satu buku kegemarannya, semenjak kelas 1 SMA. Buku yang selalu dibawanya kemanapun dirinya pergi. Lembaran buku tersebut telah lusuh. Pinggiran kertasnya pun melekuk-lekuk karena terlalu sering dibaca dan dibawa kemanapun Bianca pergi. Deskripsi cerita tersebut berbeda saat diadaptasi ke dalam film. Dalam film terjadi perubahan bervariasi ketika film di awali dengan perkenalan antara Bianca dan Letisha kecil.

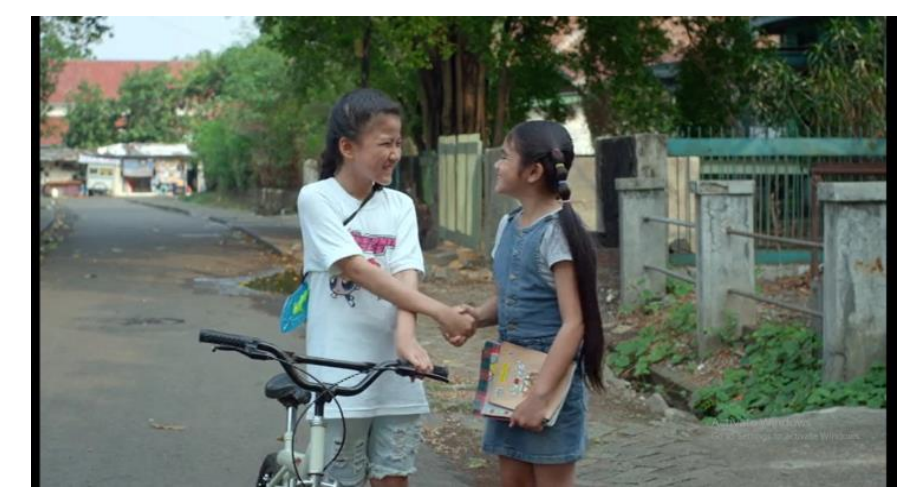

Gambar 1. Adegan Letisha dan Bianca Berkenalan pada Masa Kecil (Sumber: Film Raksasa dari Jogja) 
Gambar 1 menunjukkan adegan ketika Bianca dan Letisha kecil berkenalan. Pembukaan film dibuka dengan adegan ketika Bianca kecil diganggu oleh beberapa anak kecil lainnya saat sedang bermain di jalan. Kemudian Letisha kecil datang dan menjadi pahlawan untuk membantu Bianca. Letisha pada Gambar 1 adalah gadis kecil yang mengenakan baju berwarna putih, sedangkan Bianca gadis kecil yang mengenakan baju terusan rok jeans. Pakaian yang digunakan Letisha menunjukkan bahwa ia gadis yang lebih tomboi dari Bianca. Terlihat pula pada adegan Letisha membantu Bianca dari kenakalan beberapa anak lelaki yang mengganggu Bianca. Pada akhirnya, mereka saling memperkenalkan diri satu sama lain. Mereka kemudian berjabat tangan lalu berteman. Hari itu Letisha berjanji untuk selalu menjaga Bianca. Karena Bianca tidak berani melawan anakanak yang mengganggunya.

Perubahan bervariasi tersebut terjadi agar pembukaan cerita lebih menarik sekaligus mengenalkan persahabatan Bianca dan Letisha yang telah terjalin sejak kecil menjadi lebih singkat. Penceritaan yang berbeda dalam novel yang mengenalkan tokoh Bianca sebagai pribadi yang menggemari membaca buku-buku fiksi. Perubahan ini bukan tanpa tujuan. Tujuannya agar dari sisi konten lebih menarik menghadirkan konflik dialami oleh Bianca dalam film, dibandingkan dengan teks naratif novelnya. Sebagai karya fiksi, aspek konflik sebagai konten cerita jauh lebih memberikan kesan impresif dan emosional bagi penonton film atau pun pembaca novel. Ketegangan-ketegangan dalam karya fiksi merupakan salah satu daya tarik cerita. Sehingga hasil adaptasi film berbeda dengan konten cerita novelnya. Apalagi medium film lebih menarik sebagai tontonan, dibandingkan dengan medium membaca teks buku. Perbedaan medium inilah yang mengakibatkan perubahan bervarisasi pada alur cerita.

\section{Perubahan pada Latar}

Perubahan bervariasi pada latar pada novel terjadi ketika menceritakan pertemuan pertama kalinya antara Gabriel dan Bianca. Bianca diceritakan sedang menunggu bus Trans Jogja di shelter bus Trans Jogja Taman Siswa. Pertemuan antara dirinya dengan Gabriel itu bisa terjadi, ketika Bianca harus pulang sendirian dari Taman Budaya dan harus menggunakan bus untuk pulang ke rumahnya. Pertemuannya dengan Gabriel belangsung di dalam bus yang ketika itu cukup penuh dengan penumpang. Gabriel saat itu merupakan salah satu di antara berjubelnya penumpang bus.

Waktu berjalan kian lambat, sudah pukul 21.25. Bianca mendengar suara bus sayupsayup mendekati shelter. Bianca memang tak terlalu hafal bunyi bus Trans Jogja tapi ia sangat berharap bahwa itulah bus yang ia tunggu sejak tadi. Bus berwarna hijau kuning itu memberhentikan langkahnya di shelter Taman Siswa, tempat Bianca menunggu. Pandangan Bianca tertuju pada penumpang yang ada di dalam bus. Bus memang terlihat cukup penuh. (Raksasa dari Jogja:77).

Data menunjukkan latar tempat yaitu lokasi shelter Trans Jogja. Bianca berada di shelter bus Tran Jogja Tama Siswa untuk menunggu bus yang akan membawanya pulang ke rumahnya. Ketika bus Trans Jogja datang, Bianca pun bertemu dengan Gabriel untuk pertama 
kalinya. Saat bus Trans Jogja tiba di shelter, Bianca dan penumpang yang sedari tadi juga menunggu pun bergerombol dan berdesak-desakan berebut untuk menaiki bus. Selain, Bianca terdesak penumpang yang akan memasuki bus, dia juga terdesak pula oleh penumpang yang akan turun. Saat itu, Bianca dihimpit oleh penumpang lain yang berdesakan tersebut. Lantas sosok Gabriel hadir di depannya dan menubruk tubuh mungilnya dengan maksud untuk melindunginya dari kerumunan penumpang. Sedangkan pada film terjadi perubahan bervariasi ketika pertemuan antara Bian dan gabriel terjadi sama-sama di halte. Akan tetapi, pada film mereka pertama kali bertemu di halte Trans Jakarta dan bukan di halte Trans Jogja.

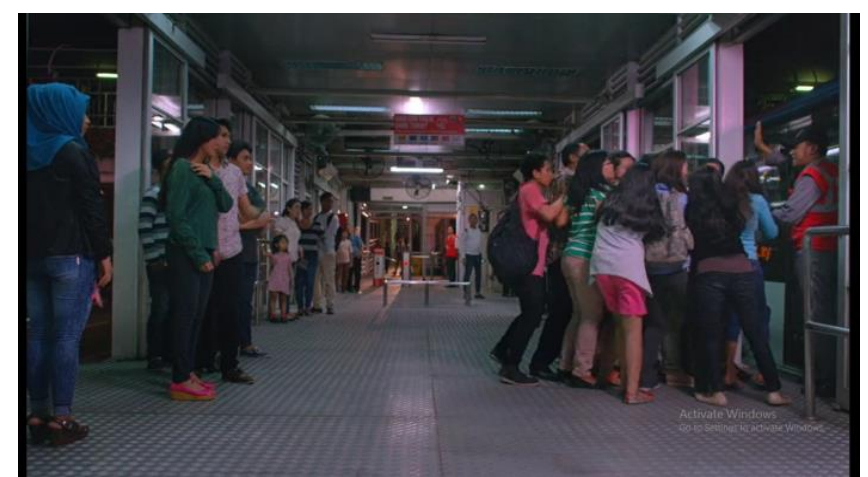

Gambar 2. Adegan Bianca Berdesakan dengan Penumpang Lain di Halte Trans Jakarta (Sumber: Film Raksasa dari Jogja)

Gambar 2 menunjukkan adegan ketika Bianca berada di halte Trans Jakarta ketika hendak pulang ke rumahnya dengan menggunakan bus. Adegan menceritakan ketika Bianca tengah berdesakan dengan penumpang lain yang hendak menaiki bus. Shelter bus Trans Jakarta merupakan awal pertemuannya dengan Gabriel. Laki-laki yang menolongnya dari desakan penumpang yang tidak tertib.

Adegan di film mengalami pengubahan latar. Semula dalam teks naratif novel latarnya adalah shelter bus Trans Jogja menjadi shelter bus Trans Jakarta. Peristiwa dalam adegan tersebut dikarenakan, perkenalan Bianca dengan Gabriel di film pertama kali justru berlangsung di Jakarta. Ketika itu, Bianca masih berada di Jakarta dan belum pindah ke Yogyakarta untuk menempuh kuliah.

Deskipsi data dan analisis data menunjukkan bahwa berlangsung pengubahan latar antara novel dengan filmnya. Artinya, sebagai produk adaptasi film Raksasa dari Jogja mengalami pengubahan yang tidak sama dengan sumber aslinya. Sutradara secara sadar mengubah latar film tidak sama dengan sumber novel sebagai karya rujukannya. Bahkan ada intervensi kreatif dari sutradara dengan menambahkan aspek unsur cerita Bianca tinggal di Jakarta dan baru pindah ke Yogyakarta untuk kuliah. Sutradara memandang cerita kehidupan Bianca dalam novel kurang dramatis atau kurang kompleks, sehingga dalam film diubah dengan memberikan dramatika cerita bahwa antara Gabriel dan Bianca bertemu di shelter bus di Jakarta. Dalam pola adaptasi hal ini diperbolehkan dilakukan adanya penambahan aspek cerita, terutama untuk memberikan sisi dramatisasi cerita. 


\section{Perubahan pada Tokoh}

Novel Raksasa dari Jogja menceritakan saat Bianca dari dalam kamarnya mendengarkan pertengkaran antara kedua orang tuanya. Bianca berusaha untuk tidak mendengarkan pertengkaran tersebut dengan mecoba mendengarkan music dari iPodnya. Namun begitu, pada akhirnya Bianca tidak tahan juga dengan pertengkaran kedua orang tuanya.

\section{PRANG !!}

Kesunyian di kamar Bianca sontak pecah oleh suara yang memang tak asing baginya. Ia menghela napas.

Dengan sigap, ia langsung meraih iPod. Gerad Way, vokalis My Chemical Romance bernyanyi dengan volume sangat keras. Dentuman drum dan petikan gitar listrik berlomba-lomba memenuhi telinga Bianca, buku segera ia raih. Ia sangat hafal bunyi itu. (Raksasa dari Jogja:5).

Data menunjukkan keadaan tokoh Bianca dalam novel ketika mendengar pertengkaran yang terjadi di antara kedua orang tuanya. Pertengkaran yang sudah tidak asing lagi baginya. Ketika mendengar keributan kedua orang tuanya, Bianca selalu berusaha untuk mengabaikan dan mengalihkan perhatiannya agar tidak mendengarkan pertengkaran tersebut. Upaya yang dilakukannya tersebut salah satunya dengan cara menggunakan iPod dan mendengarkan lagu dengan volume yang sangat keras. Tujuannya agar ia tidak mendengar pertengkaran tersebut. Selain itu, Bianca juga berusaha dengan membaca buku, meskipun konsentrasinya membaca terganggu dan menyebabkan dirinya tidak berminat membaca lagi. Namun, Bianca masih berusaha dengan memilih tetap berada di balik selimut hangatnya dan kembali memperhatikan setiap kalimat yang tercetak di buku. Sedangkan pada film, ketika Bianca berada di dalam kamarnya dan mendengar pertengkaran yang mulai terjadi di antara kedua orang tuanya hal tersebut tidak dilakukan oleh Bianca. Bianca hanya duduk termenung di ujung ranjangnya sambil mendengarkan pertengkaran kedua orangnya.

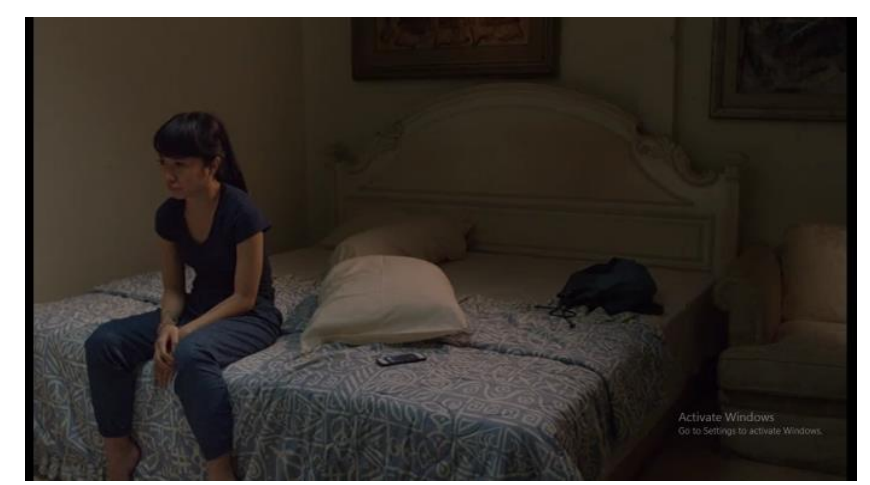

Gambar 3. Adegan Bianca Berada di Dalam Kamar dan Mendengarkan Pertengkaran Kedua Orang Tuanya (Sumber: Film Raksasa dari Jogja)

Gambar 3 menunjukkan adegan ketika Bianca berada di kamarnya. Adegan memperlihatkan Bianca tengah mendengarkan pertengkaran kedua orang tuanya. Bianca 
hanya duduk termenung dalam diam di ujung tempat tidurnya, tanpa berusaha untuk mengalihkan perhatiannya dengan cara mendengarkan musik atau membaca buku sebagaimana yang dikisahkan di novel. Bianca lebih memilih untuk berdiam diri dan mendengarkan pertengkaran kedua orang tuanya. Ia merenungkan segala pertengkaran yang ia dengar. Hal itu membuat hatinya semakin sakit. Perubahan pada adegan tersebut membuat konflik di hati Bianca semakin bertambah. Mendengarkan langsung pertengkaran kedua orang tuanya tanpa mengalihkan perhatian membuat pergulatan di hati Bianca semakin bertambah dan dirasakannya sangat menyiksa batinnya.

Deskripsi data dan analisis data menunjukkan perubahan bervariasi pada tokoh. Bagaimana konten cerita novel mengalami pengubahan ke medium film oleh sutradara. Sutradara secara sengaja mengubah adegan Bianca yang mendengar pertengkaran kedua orang tuanya dengan menampilkan sisi emosional dan psikologis Bianca secara dramatis. Bagaimana Biancan digambarkan mengalami pergulatan batin dan emosi dengan menyikapi secara emosional dalam diam. Hal ini merupakan sisi sutradara dalam mengeksploitasi psikologi Bianca yang tidak berdaya menghadapi pertengkaran kedua orang tuanya. Berbeda halnya dengan konten cerita di novel. Bagaimana Bianca memiliki penyaluran emosi dengan mendengarkan musik dan membaca buku. Secara visual justru kegalauan dan ketersiksaan batin Bianca di film sangat impresif dan menguras emosi penonton. Hal tersebut membuat film terkesan tidak seasli novelnya, akan tetapi tidak merubah garis besar penceritaan.

\section{Representasi Kearifan Lokal dalam Novel dan Film}

Novel dan film Raksasa dari Jogja dalam perspektif representasi mencerminkan kearifan lokal melalui perilaku tokoh-tokohnya. Representasi kearifan lokal ditunjukkan oleh tokoh Bianca yang gemar menonton pertunjukan tradisional dan mengunjungi tempat-tempat wisata tradisional maupun bersejarah. Berikut data dan analisis terkait representasi kearifan local yang terkandung di dalam novel dan film Raksasa dari Jogja.

\section{Kearifan Lokal pada Kesenian}

Novel Raksasa dari Jogja sebagian besar menceritakan tentang kegemaran tokoh utama Bianca terhadap kearifan lokal yang menjadi kekhasan dari Kota Yogyakarta, yaitu kesenian tradisional yang dipengaruhi oleh budaya Jawa. Tokoh Bianca mengutarakan keinginnya untuk menonton pertunjukkan Wayang Orang di Taman Budaya. Wayang Orang merupakan pertunjukkan tradisional khas masyarakat Jawa, baik yang tinggal di wilayah Yogyakarta maupun Surakarta. Selama ini kekayaan budaya tersebut menjadi ikon identitas kedua wilayah tersebut.

"Bukan ngejek. Kamu mau nonton wayang orang atau teater?"

"Wayang orang. Pasti seru!" Bianca tersenyum. Ia menopang dagunya dengan kedua tangannya. "Aku pingin lihat pementasan Mahabrata. Gara-gara baca Biola Tak Berdawai, aku jadi pingin lihat Wayang Orang." (Raksasa dari Jogja:67). 
Data menunjukkan bukti bahwa tokoh Bianca tertarik untuk menonton pertunjukkan tradisional Wayang Orang. Ketertarikannya tersebut berawal dari novel milik Seno Gumira Ajidarma yang ia baca menceritakan tentang Wayang Orang. Ternyata novel tersebut mempengaruhi Bianca yang tertarik untuk menonton wayang orang. Bianca ingin menyaksikan pementasan wayang orang dengan lakon Mahabrata di Taman Budaya. Keinginannya itu diutarakan kepada Kevin yang tercengang begitu mendengar keinginan Bianca tersebut. Keinginan yang membuat Kevin terkejut. Ia tidak menyangka jawaban Bianca sewaktu Kevin menanyakan tempat yang ingin dikunjunginya. Keinginan yang menurut Kevin sangat tidak disangka-sangkanya dan di luar pikirannya. Rupanya adik sepupunya tersebut ingin mengunjungi Taman Budaya hanya untuk menonton pertunjukkan wayang orang.

Kevin melongo mendengar penjelasan Bianca. "Aku aja, orang Jogja asli, enggak tertarik nonton wayang."

"Orang kayak kamu yang bikin hampir semua yang dimiliki Indonesia direbut Malaysia."

"Nasionalis abis!” Kevin tersenyum kecut. "Sorry, deh. Mau aku anterin?” (Raksasa dari Jogja:67).

Data menunjukkan sikap Bianca yang menjunjung tinggi kearifan lokal sebagai produksi budaya masyarakat Jawa. Sikap itu dibuktikan dengan kegemarannya menonton pertunjukkan tradisional wayang orang. Tradisi kesenian yang hampir punah di tengah peradaban modern saat ini. Bahkan banyak generasi muda yang tidak begitu tertarik menyaksikan pementasan Wayang Orang. Sebagaimana ditunjukkan oleh Kevin. Kevin mengakui di hadapan Bianca dengan mengatakan bahwa ia sebagai orang asli Yogyakarta saja tidak begitu tertarik menonton kesenian wayang orang. Menurut Bianca, sikap warga lokal yang justru tidak menghargai dan mengapresiasi kearifan lokal berupa kesenian tradisional yang dimiliki bangsanya sendiri merupakan tindakan yang tidak seharusnya ditunjukkan. Karena hal itu, membuat kekayaan Indonesia sering kali diakui kepemilikannya oleh negara lain.

Penononton yang datang pada pertunjukkan itu juga beragam. Mereka berasal dari status dan strata sosial yang berbeda. Orang kantoran, mahsiswa, pelajar, dan pengamat seni, ada yang membawa pasangannya, ada juga yang bersama temantemannya. Begitu indahnya kebersamaan itu terekam. (Raksasa dari Jogja:71).

Data menunjukkan situasi yang tergambar di Taman Budaya, ketika pertunjukan Wayang Orang berlangsung. Bianca memutuskan untuk menonton pertunjukan itu sendirian. Taman Budaya pun dipadati oleh para penonton yang sengaja datang untuk menonton pertunjukkan Wayang Orang. Situasi keramaian penonton tergambar dari beragamnya penonton yang berasal dari berbagai strata sosial dan profesi yang berbeda-beda. Hal tersebut menandakan pertunjukkan kesenian Wayang Orang masih dinikmati oleh berbagai kalangan di masa kini. Artinya, masyarakat Yogyakarta, baik warga lokal maupun wisatawan masih menghargai kesenian Wayang Orang sebagai produk budaya yang berasal dari kearifan lokal 
Representasi Kearifan Lokal dari Novel ke Film Raksasa dari Jogja: Kajian Ekranisasi (Ajeng Yuditya Siswara, Heru S.P. Saputra, Titik Maslikatin)

masyarakat yang hidup dalam kebudayaan Jawa. Pertunjukan ini masih sering ditemukan pada berbagai acara kesenian, terutama di wilayah Kota Yogyakarta dan sekitarnya.

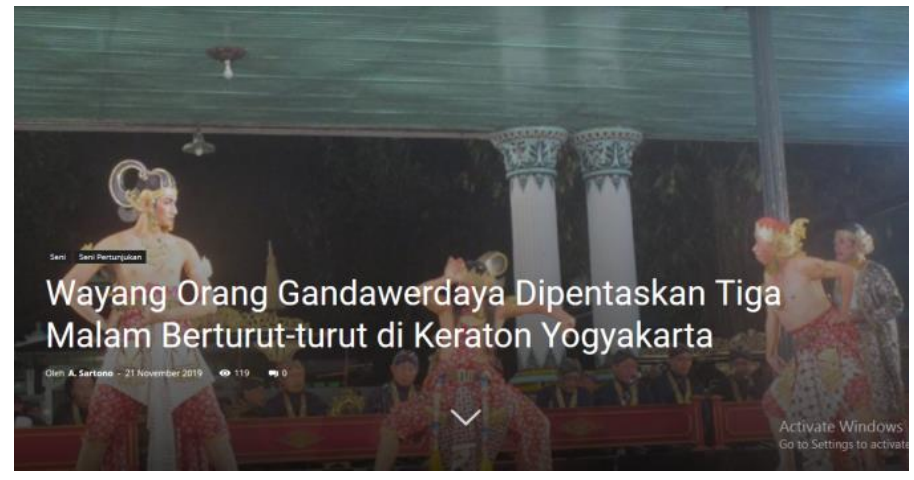

Gambar 4. Pagelaran Wayang Orang

(Sumber: https://www.tembi.net/)

Gambar 4 menunjukkan pertunjukkan kesenian Wayang Orang Gandawardaya yang dipentaskan tiga malam berturut-turut di keraton Yogyakarta. Fakta tersebut merupakan realitas sosial bahwa kesenian tradisional Wayang Orang masih dipentaskan hingga saat ini. Acara pementasan kesenian Wayang Orang Gandawardaya diadakan dalam rangka memeriahkan perayaan Sekaten 2019. Hingga tahun 2019 pertunjukan Wayang Orang masih sering ditampilkan pada berbagai acara di Yogyakarta.

Kesenian Wayang Orang merupakan salah satu bentuk seni pertunjukkan tradisional Jawa, khususnya Jawa Tengah. Cerita ini sudah menyatu dengan masyarakat setempat, dimainkan berdasarkan kisah nyata Mahabrata dan Ramayana yang mengandung pesan moral. Penonton serasa terbawa kembali ke zaman dahulu dengan tata panggung yang unik dan eksotis. Pada abad ke-18 Wayang Orang pertama kali muncul di Solo, diciptakan oleh KGPAA Mangkunegoro I. Seni pertunjukan ini terinspirasi dari seni drama yang berkembang di Eropa. Kemudian pada tahun 1899, Paku Buwono X meresmikan Taman Sriwedari sebagai taman hiburan untuk umum, dan pada saat itu ada pementasan pertunjukkan Wayang Orang yang hingga kini tetap bertahan (Sartono, 2019).

Data di atas menunjukkan pada dunia nyata kesenian Wayang Orang adalah representasi atas kesenian asli Indonesia. Produk kebudayaan nenek moyang yang sudah ada sejak abad ke-18. Pertunjukan Wayang Orang selama ini dalam pementasannya didasarkan dari kisah Mahabrata dan Ramayana. Pertunjukan kesenian ini telah menyatu dengan masyarakat di Surakarta maupun Yogyakarta. Hal ini terbukti ketika pada tahun 1980-an, kesenian Wayang Orang menjadi sebuah tontonan yang paling menarik untuk masyarakat Indonesia. Bahkan hingga turis mancanegera. Tidak hanya pada tahun 1980-an saja, pertunjukan ini masih menjadi pertunjukan yang digemari hingga saat ini. Meskipun sempat mengalami penurunan penonton, akan tetapi kesenian Wayang Orang masih dapat mempertahankan eksistensinya. Oleh karena itu, pada zaman sekarang ini tidak kehilangan peminatnya. Bahkan ada juga dari kalangan generasi muda sebagai penontonnya. Meskipun secara kuantitatif tidak signifikan dibandingkan dengan penikmat seni Wayang Orang dari generasi dahulu. 


\section{Kearifan Lokal pada Pariwisata}

Daya tarik wisata alam wilayah kota Yogyakarta salah satunya adalah kawasan Gunung Merapi. Gunung Merapi selama ini menjadi ikon salah satu tempat yang melekat dengan identitas kota Yogyakarta. Erupsi Gunung Merapi pada 2010 yang telah melululantahkan kota Yogyakarta namun membawa berkah dengan menjadikan wilayah tersebut sebagai salah satu ikon wisata alam. Gunung Merapi tetap menjadi kebanggaan masyarakat Yogyakarta. Banyak wisatawan lokal dan mancanegara yang mengunjungi obyek wisata alam Gunung Merapi.

Pandangannya kini mengarah pada jendela yang terbuat dari kayu. Ia merayap keluar dari selimut, lalu merapikan tempat tidurnya. Bianca membuka jendela perlahan. Merapi dengan santainya tebar pesona, menghadiahi Bianca dengan pemandangan yang sempurna. Mulut Bianca melongo, perlahan-lahan Bianca sadar bahwa ada jutaan alasan mengapa masyarakat Jogja begitu mencintai gunung ini, meskipun gunung yang dicintai kerap merusak dan melululantakkan kota. (Raksasa dari Jogja:120).

Data menunjukkan kekaguman Bianca akan keindahan Gunung Merapi. Pesona gunung ini mampu mencuri perhatian Bianca. Letusan Merapi beberapa tahun silam tidak membuat gunung ini kehilangannya pesonanya. Justru keindahan alam Gunung Merapi masih terpancar dan begitu mengagumkan. Bianca yang mengikuti orientasi kampus yang diadakan di Gunung Merapi merasa beruntung dapat menikmati suasana pagi di gunung tersebut. Ia menyadari hal yang membuat gunung ini tetap dicintai oleh masyarakat Yogyakarta, meskipun pernah melululantakkan kota akibat erupsinya pada tahun 2010 silam. Kedahsyatan letusan Gunung Merapi pada saat itu justru membuat Gunung Merapi menjadi tempat wisata yang ramai dikunjungi wisatawan pada masa kini. Fakta hingga saat ini bahwa Gunung Merapi menjadi tempat wisata yang banyak dikunjungi oleh para wisatawan.

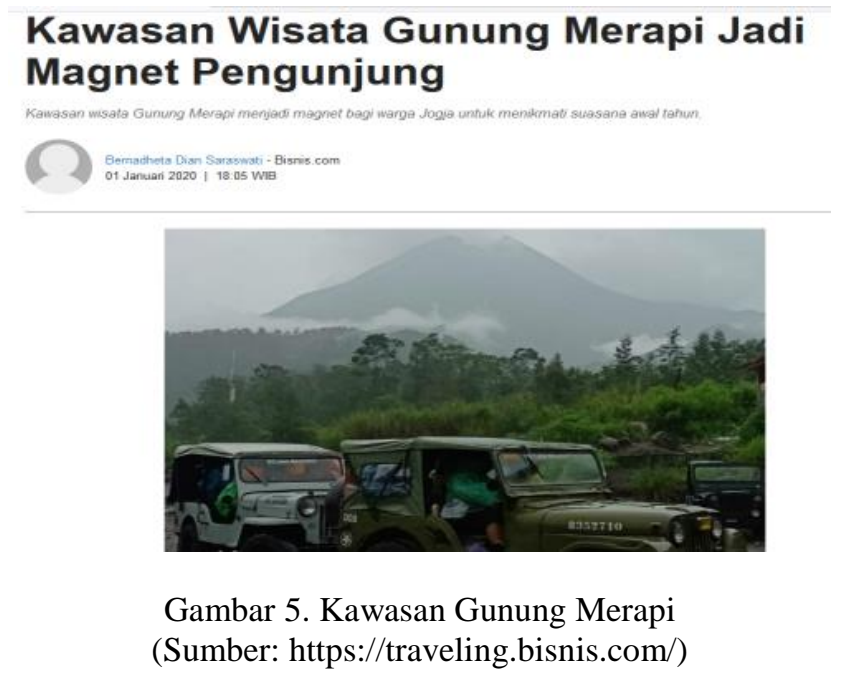

Gambar 5 menunjukkan realitas bahwa Gunung Merapi menjadi magnet pengunjung untuk berwisata di tempat ini. Wisatawan berkunjung kemari bersama sama teman maupun 
sanak saudaranya. Tempat ini juga dijadikan tempat berkemah bagi para pengunjung. Kondisi alam di Gunung Merapi mendukung bagi upaya wisata alam, termasuk untuk aktivitas berkemah. Alamnya yang masih alamai dan udaranya yang segar terbebas dari polusi maupun hamparan tanaman yang hijau merupakan daya tarik tersendiri bagi wisatawan. Bahkan di gunung Merapi terdapat museum sewaktu terjadi erupsi.

Gunung Merapi merupakan salah satu gunung berapi yang paling aktif di Indonesia. Ketinggian mencapai 2.930 Mdpl. Gunung Merapi dinyatakan sebagai salah satu gunung yang berbahaya. Setiap dua sampai lima tahun sekali Merapi tercatat mengalami erupsi, sementara masih terdapat pemukiman yang cukup padat di sekitarnya. Masih terdapat tempat pemukiman penduduk di lereng Merapi yang hanya berjarak sekitar $4 \mathrm{~km}$ dari puncak gunung. Sisi Selatan lereng Gunung Merapi berada di wilayah Kabupaten Sleman, sementara pada bagian lainnya masuk wilayah Jawa Tengah. Tercatat letusan terakhir Merapi yang cukup dahsyat terjadi pada Oktober dan November 2010 dengan jumlah korban meninggal mencapai 273 jiwa. Kedahsayatan letusan berupa suara ledakan dan gemuruh bahkan dapat terdengar hingga radius $20-30 \mathrm{~km}$. Selain hujan abu vulkanik, hujan pasir dan kerikil juga mencapai wilayah Yogyakarta (Saraswati, 2020).

Gunung Merapi meskipun disebut sebagai salah satu gunung yang berbahaya, namun pada kenyataannya banyak wisatawan yang tertarik untuk menjelajah Gunung Merapi dan menyaksikan keindahan alamnya yang begitu berbeda. Vegetasi yang dulu menjadi kawasan hutan di sekitar Merapi yang tidak lagi menghijau justru menjadi daya tarik tersendiri yang diminati oleh wisatawan. Hal ini dibuktikan dengan adanya wisata Lava Tour. Potensi wisata yang unik dan berbeda di kawasan Gunung Merapi menjadi saksi keganasan erupsi yang telah terjadi di masa silam. Selain kegiatan wisata Lava tour ada beberapa tempat wisata di kawasan Merapi yang menarik untuk dikunjungi, di antaranya Museum Gunung Merapi yang di dalamnya terdapat replika sebaran panas Gunung Merapi, sebuah alat yang akan membuat ruangan bergemuruh dan aliran lava pijar serta awan panas akan terlihat seperti kejadian saat erupsi berlangsung, wisata Kali Adem yang terdapat sebuah batu dengan bentuk menyerupai wajah manusia dan seting disebut dengan istilah wajah alien, Wisata Bunker yang dibangun sebagai tempat untuk berlindung ketika terjadi erupsi, dan wisata rumah kediaman Mbah Marijan salah satu sosok juru kunci Gunung Merapi fenomenal karena keteguhannya yang enggan meninggalkan lokasi pada saat terjadi erupsi.

Deskripsi di atas dapat dibuktikan bahwa Merapi menjadi salah satu kearifan lokal yang menarik wisatawan untuk berkunjung ke Yogyakarta. Baik masyarakat lokal maupun wisatawan masih tertarik mengunjungi gunung yang pernah melululantahkan kota ini. Pesona Merapi tidak ada habisnya seperti yang dikatakan oleh tokoh Bianca pada novel bahwa ada jutaan alasan mengapa masyarakat Yogyakarta menyayangi gunung ini meski gunung yang dicintai kerap merusak dan melululantakkan kota. Sisa-sisa erupsi justru menjadi wisata baru yang menarik dikunjungi karena mengingatkan kita akan dahsyatnya erupsi yang terjadi.

Berdasarkan paparan data dan analisis bahwa novel Raksasa dari Jogja mengandung unsur cerita yang merepresentasikan kearifan lokal. Kearifan lokal ini berupa produk kebudayaan yang berbentuk kesenian tradisional Wayang Orang dan wisata alam yang menjadi destinasi menarik bagi masyarakat, yaitu alam Gunung Merapi. Bahkan keduanya menjadi ikon 
identitas kota Yogyakarta. Bagi tokoh Bianca bahwa kesenian Wayang Orang dan obyek wisata alam Gunung Merapi merupakan representasi dari kearifan lokal yang menjadi penanda atas identitas masyarakat dan wilayah Kota Yogyakarta. Keduanya berfungsi sebagai reprsentasi simbol identitas. Hasil analisis representasi, peneliti menemukan representasi kearifan lokal Yogyakarta. Representasi tersebut meliputi kesenian sebagai kearifan lokal, dan pariwisata sebagai kearifan lokal.

\section{SIMPULAN}

Proses ekranisasi yang terjadi antara novel Raksasa dari Jogja dan film hasil adaptasinya mengalami perubahan. Perubahan memungkinkan terjadi dikarenakan alat utama novel adalah kata-kata dan harus diubah menjadi film yang alat utamanya adalah gambargambar yang bergerak (visual). Perubahan terjadi pada teks novel dan teks film yang berupa beberapa penciutan pada alur, tokoh, dan latar. Hal ini dikarenakan teks cerita dalam novel kurang menarik apabila divisualisasikan dalam bentuk film. Bahkan jika tidak ditampilkan pun tidak akan berpengaruh terhadap jalan cerita atau alur. Penambahan pada alur, tokoh, dan latar yang terjadi dalam film bertujuan untuk membuat penceritaan semakin menarik dari sisi dramatisasi cerita.

Perubahan bervariasi yang terjadi pada alur, tokoh, dan latar dikarenakan tidak semua kisah dalam novel dapat divisualisasikan sama persis pada filmnya, sehingga mengharuskan sutradara melakukan perubahan variasi-variasi tertentu. Proses perubahan yang terjadi antara novel dan film Raksasa dari Jogja secara garis besar tidak merubah substansi novelnya. Garis besar penceritaan pada novel tetap dapat divisualisasikan dengan baik meskipun harus mengalami proses perubahan.

Representasi kearifan lokal dalam novel Raksasa dari Jogja terlihat dari produk kebudayaan yang menjadi identitas dari masyarakat maupun wilayah Yogyakarta, yaitu kesenian tradisional Wayang Orang dan pariwisata alam Gunung Merapi. Representasi eksistensi kesenian Wayang Orang dan Pariwisata alam Gunung Merapi merupakan bentuk pengejawantahan ideologi pengarang yang ingin disampaikan kepada pembaca. Hal ini ditunjukkan dengan pengisahan tokoh utama Bianca yang menggemari kesenian Wayang Orang yang merupakan peninggalan warisan kebudayaan dan sejarah yang melegenda maupun kekagumannya terhadap alam Gunung Merapi. Keduanya merupakan representasi atas kearifan lokal yang menjadi ikon identitas.

\section{DAFTAR PUSTAKA}

Anoegrajekti, N. 2010. Identitas Gender: Kontestasi Perempuan Seni Tradisi. Jember: Kelompok Peduli Budaya dan Wisata Daerah Jawa Timur.

Damono, S.D. 2018. Alih Wahana. Jakarta: Gramedia Pustaka Utama.

Eneste, P. 1991. Novel dan Film. Yogyakarta: Nusa Indah.

Faruk. 2012. Metode Penelitian Sastra: Sebuah Penjelajahan Awal. Yogyakarta: Pustaka Pelajar.

Fiske, J. 2011. Memahami Budaya Popular. Diterjemahkan Mahyudin, A.B. Yogyakarta: Jalasutra. 
Representasi Kearifan Lokal dari Novel ke Film Raksasa dari Jogja: Kajian Ekranisasi (Ajeng Yuditya Siswara, Heru S.P. Saputra, Titik Maslikatin)

Hall, S. 1997. Representation: Cultural Reprsentation and Signifying Practices. London: Sage Publication.

Keerigan, F. 2010. Film Marketing. Butterworth-Heinemann: Elsiever Ltd.

Maleong, L. 2010. Metode Penelitian Kualitatif. Bandung: Remaja Rosdakarya.

Poerwadarminta, W.J.S. 1979. Bahasa Indonesia untuk Karang-Mengarang. Yogyakarta: U.P. Indonesia.

Saputra, H.S.P. 2009. "Tranformasi Lintas Genre: dari Novel ke Film, dari Film ke Novel." Humaniora, 21 (1):41-55.

Saraswati, B.D. 2020. "Kawasan Wisata Gunung Merapi Jadi Magnet Pengunjung" https://traveling.bisnis.com/read/20200101/224/1186065/kawasan-wisata-gunungmerapi-jadi-magnet-pengunjung . (Diakses 24 Februari 2020).

Sartono, A. 2019. "Wayang Orang Gandawerdaya Dipentaskan Tiga Malam Berturut-turut di Keraton Yogyakarta." https://www.tembi.net/2019/11/21/wayang-oranggandawerdaya-dipentaskan-tiga-malam-berturut-turut-di-keraton-yogyakarta/. (Diakses 19 Februari 2020).

Sugiyono. 2013. Metode Penelitian Pendidikan: Pendekatan Kuantitatif, Kualitatif, dan $R \& D$. Bandung: Alfabeta. 